\title{
FACTORS AFFECTING THE DILUTION, FREEZING AND STORAGE OF HUMAN SEMEN
}

\author{
M. FREUND AND J. WIEDERMAN \\ Laboratory of Reproductive Pharmacology, Departments of Pharmacology \\ and of Obstetrics and Gynecology, New York Medical College, \\ Flower and Fifth Avenue Hospitals, New York, U.S.A.
}

(Received 4th Fanuary 1965, revised 1st April 1965)

\begin{abstract}
Summary. The presence of a true 'dilution effect', as opposed to the toxic effects of certain diluents, was indicated in experiments where human semen was diluted $1: 1,1: 5,1: 25$ and $1: 125$ with six different diluents. Norman-Johnson-Solutions 1 and 2 were found to be superior to all other diluents tested and were shown to be equally useful as media in the freezing of diluted human semen. Twenty-one freezing trials were made, using the technique as developed to this point$1: 5$ dilution with Norman-Johnson-Solutions 1 or 2, the addition of $10 \%$ egg yolk, slow cooling from +25 to $+5^{\circ} \mathrm{C}$ over a 4-hr period, $6 \mathrm{hr}$ of equilibration with $7 \%$ glycerol at $+5^{\circ} \mathrm{C}$, slow freezing from +5 to $-70^{\circ} \mathrm{C}$ at the rate of $-1^{\circ} \mathrm{C} / \mathrm{min}$, and storage at temperatures of -76 to $-85^{\circ} \mathrm{C}$. Motility ratings made on the day after freezing indicated that 75 to $100 \%$ of the motile cells frozen were recovered alive and motile, displaying vigorous forward progression. In none of the twenty-one trials was less than $75 \%$ of the motile cells frozen, recovered alive and motile. Storage at -76 to $-85^{\circ} \mathrm{C}$ for periods up to 10 months resulted in spermatozoal motility ratings almost equal to that after one day of storage, although there was a substantial loss in motility upon further storage in this temperature range during months 10 to 24. Longterm storage of diluted human semen without considerable loss of motility would seem to require lower storage temperatures, i.e. that of liquid nitrogen, $-196^{\circ} \mathrm{C}$.
\end{abstract}

\section{INTRODUCTION}

The recovery of small numbers of motile spermatozoa after the freezing of human semen to $-79^{\circ}$ or to $-196^{\circ} \mathrm{C}$ was reported by Jahnel (1938), Shettles (1940), Hoagland \& Pincus (1942) and Parkes (1945). However, it was not until Polge, Smith \& Parkes (1949) discovered that glycerol could be used to protect most mammalian spermatozoa, including human spermatozoa, from freezing damage that the recovery of large numbers of motile spermatozoa became possible.

Sherman \& Bunge (1953) reported methods for the rapid freezing of raw 
human semen with the addition of $10 \%$ glycerol and used the frozen semen for artificial insemination, but did not report data on the percentage recovery of motile spermatozoa after freezing and storage. Bunge (1960) has continued this work and is freezing raw human semen with $10 \%$ glycerol in a dry ice cabinet at a rapid rate ('fast freezing'), since he states that the 'specimens were usually frozen solid within $5 \mathrm{~min}$ ', but no data on pre- or post-freezing motilities are presented. Sherman (1954, 1955, 1962), working independently, has continued to report methods for the fast freezing $\left(\cong-25^{\circ} \mathrm{C} / \mathrm{min}\right.$ ) of raw human semen 'over the surface of liquid nitrogen', but did not include data on the survival of the spermatozoa as ratings of sperm motility. In 1963 he presented the first data based on pre- and post-freezing motility ratings on thirty specimens from fifteen donors, which indicated that raw human semen (mean motility = $50 \%$ ) with $10 \%$ glycerol added, fast frozen either with dry ice or with liquid nitrogen, had mean post-thaw motilities of $29 \%$ and $35 \%$ respectively. Zimmerman, Maude \& Moldawer (1964), using a similar technique, froze specimens from fifty donors (mean motility $=67.9 \%$ ) with liquid nitrogen and reported a comparable mean post-thaw motility of $26 \%$. Recently, however, Perloff, Steinberger \& Sherman (1964), using the same technique with six high quality specimens selected for artificial insemination (mean spermatozoal concentration $=132.7$ million $/ \mathrm{ml}$ and mean motility $=82.5 \%$ ), reported a much higher post-thaw motility $(61 \cdot 7 \%)$.

The important scientific and practical achievements resulting from the use of frozen bull semen are based on the fact that methods have been developed to dilute bull semen without marked loss of viability or fertility so that, after the freezing and storage of the diluted semen, it is possible to inseminate a large number of cows with the spermatozoa from a single ejaculate. The preparation of many ampoules of frozen diluted semen from a single ejaculate also makes it practical to replicate so that duplicate ampoules may be prepared and examined at intervals, treatment effects may be quantitatively measured and the variance among ampoules treated alike may be used as an error term to test for the significance of treatment differences. Studies based on frozen raw (undiluted) human semen must remain qualitative or, at best, semi-quantitative since there is not enough volume in a single ejaculate $(1$ to $4 \mathrm{ml}$ ) to permit treatment replication or the calculation of an error variance term. Frozen raw human semen is essentially a fascinating scientific curiosity which can be used to produce a limited number of conceptions. The use of frozen diluted human semen is a prerequisite for controlled and replicated investigations and for practical studies of the fertility of frozen human semen in artificial insemination.

The work with raw human semen, by Sherman \& Bunge (1953), Bunge \& Sherman (1954) and Bunge (1960) and by Sherman (1954, 1955, 1962, 1963), was based on 'fast freezing', i.e. $\cong-25^{\circ} \mathrm{C} / \mathrm{min}$, a procedure which is radically different from the 'slow freezing', i.e. -1 or $-2^{\circ} \mathrm{C} / \mathrm{min}$, which was originally reported for human semen (Polge, Smith \& Parkes, 1949) and which is widely used for the freezing of bull semen for artificial insemination (Mixner, 1955; VanDemark, Miller, Kinney, Rodriguez \& Friedman, 1957). In view of the fact that neither Bunge nor Sherman reports any contra-indication to the slow freezing of human semen or any comparison of the effects of slow and of fast 
freezing on the viability of spermatozoa, and since spermatozoal survival after fast freezing is variable and relatively poor, it seemed advisable to reinvestigate the slow freezing procedure and its effect on human spermatozoal survival after freezing.

It has been noted (White, 1954) that human spermatozoa rapidly lose their motility upon dilution with the conventional phosphate diluents widely used for bull semen. We have also found (MacLeod \& Freund, 1958; Freund \& MacLeod, 1958) that dilution of human semen with $0.25 \mathrm{M}$-disodium phosphate or with a more complex phosphate buffer (after White, 1954) at $1: 1$ or $1: 5$ dilutions, resulted in a reduction in spermatozoal metabolism and in a rapid loss of motility. Harvey (1960), measuring the actual speed of human spermatozoa with a new technique, reported that dilution of semen at $1: 10$ with seminal plasma, normal saline, or 'glucose-phosphate' resulted in a fall in average speed, with the artificial diluents causing less of a fall than did the seminal plasma. Recently, Norman, Goldberg, Porterfield \& Johnson (1960) and Norman, Johnson, Porterfield, Goldberg \& Dunbar (1961) have reported that complex tissue culture media, Norman-Johnson-Solution 1 ('N-J-l') and Norman-Johnson-Solution 2 ('N-J-2'), may be used to maintain the viability of washed bull and human spermatozoa for several days at room temperature. It occurred to us that these media might be useful for the dilution of human semen for freezing experiments.

The plan of this investigation was to find suitable diluents and dilution rates for freezing human semen, to study the effects of protective substances, e.g. glycerol, and of additives, e.g. egg yolk, on the survival of the spermatozoa in the diluted semen after freezing and storage, and to determine whether slow freezing, i.e. $-1^{\circ} \mathrm{C} / \mathrm{min}$, was suitable for the preservation of diluted human semen.

Preliminary reports on several phases of this work have been made (Freund \& Wiederman, 1962, 1963, 1964).

\section{METHODS}

The semen specimens used in these studies were received from medical students and the procedures involved in the collection, reception and examination of these specimens have been previously described in detail (Freund, 1962, 1963).

The diluents were made up in quantities sufficient for the entire study and were stored as aliquots in small bottles at $-20^{\circ} \mathrm{C}$. An aliquot of each of the diluents was thawed on each day of the study.

While specific procedures have been varied in the different experiments, in order to study their effects, the general technique evolved up to this time includes the following steps:

(1) Semen smears are made and motilities read after $10 \mathrm{~min}$ at $37^{\circ} \mathrm{C}$ in a slide warmer. Similar motility observations are made following steps (1) to (4) listed below. The raw semen is added to a $25-\mathrm{ml}$ Erlenmeyer flask with T stopper which contains one-half the volume of diluent and one-half the volume of egg yolk to be used in the experiment. The addition is made while the flask is on a magnetic stirrer and the contents are thoroughly stirred. 
(2) The flask is suspended in $400 \mathrm{ml}$ of water at room temperature (@ $25^{\circ} \mathrm{C}$ ) in a $600-\mathrm{ml}$ beaker and is allowed to cool down slowly to $5^{\circ} \mathrm{C}$ over a period of 3 to $4 \mathrm{hr}$ in a $5^{\circ} \mathrm{C}$ constant-temperature chamber.

(3) The other fraction of the final mixture, containing one-half the volume of diluent, one-half the volume of egg yolk and all of the glycerol, is made up, thoroughly stirred on a magnetic stirrer and cooled to $5^{\circ} \mathrm{C}$ with constant stirring. This fraction is then added to the fraction containing the cells, dropwise with constant magnetic stirring at $5^{\circ} \mathrm{C}$, in six equal aliquots at 10 -min intervals.

(4) The diluted and glycerolated semen is allowed to 'equilibrate' with constant magnetic stirring at $5^{\circ} \mathrm{C}$ for $6 \mathrm{hr}$.

(5) The diluted and 'equilibrated' semen is pipetted into labelled and precooled I-ml 'pull-seal' glass ampoules with a precooled syringe at $5^{\circ} \mathrm{C}$. The ampoules are sealed with an automatic ampoule sealer, using a propane-oxygen mixture.

(6) The ampoules are placed in a rack under the surface of isopropyl alcohol, in an 11.5 litre bath and frozen at the rate of $-1^{\circ} \mathrm{C} / \mathrm{min}$ from +5 to $-70^{\circ} \mathrm{C}$. The automatic set-up for the programmed, controlled and recorded freezing of semen has been described in detail (Freund \& Wiederman, 1963). The ampoules are then rapidly transferred to a mechanical refrigerator with a dry ice reserve, set at $-85^{\circ} \mathrm{C}$ and a permanent record of the storage temperature is kept.

(7) The ampoules are quickly thawed by placing them under the surface of rapidly stirred water in $\mathrm{a}+5^{\circ} \mathrm{C}$ constant temperature bath for $10 \mathrm{~min}$. They are then transferred to a water-bath at room temperature $\left(\cong 25^{\circ} \mathrm{C}\right)$ for $10 \mathrm{~min}$ and the contents of each ampoule are poured into a 5-ml beaker and stirred. Duplicate smears are made on each slide from small drops of a constant size from a precision pipette dropper, with a cover slip placed on each drop. Two slides are prepared from each ampoule. The slides are placed in slide warmers at $37^{\circ} \mathrm{C}$ for 10 min before the readings are made and two observers read each smear. Motility is rated as percentage motility ( 0 to $100 \%)$, to the nearest $10 \%$, and as forward progression ( 0 to 10$)$, to the nearest integer.

Analyses of variance were made on the ratings of motility. Since the percentage motility ratings tend to have a binomial distribution, the arcsin transformation for percentages was made and the analyses were performed on the corresponding angles. The statistical analyses followed the methods outlined by Snedecor (1956).

Statistical analyses were not performed on the forward progression ratings since pooled semen was used in most of the experiments in this investigation. We have observed that when specimens with markedly different degrees of forward progression are pooled, there are actually several populations of cells in the pooled specimen, each with its own degree of forward progression. This becomes strikingly evident when the pooled semen is frozen and there is better survival among the cells from the specimens with the higher forward progression ratings. The result is, not infrequently, a higher forward progression rating after freezing, because more of the poorer cells have not survived the processing, freezing and storage. 


\section{RESULTS AND INTERPRETATION}

EFFECT OF DILUENT AND DILUTION RATE ON SPERM MOTILITY

Six diluents were used at four dilution rates $(1: 1,1: 5,1: 25,1: 125)$ to determine their effects on the maintenance of spermatozoal motility and forward progression over a period of $5 \mathrm{hr}$ at $25^{\circ} \mathrm{C}$. The six were:

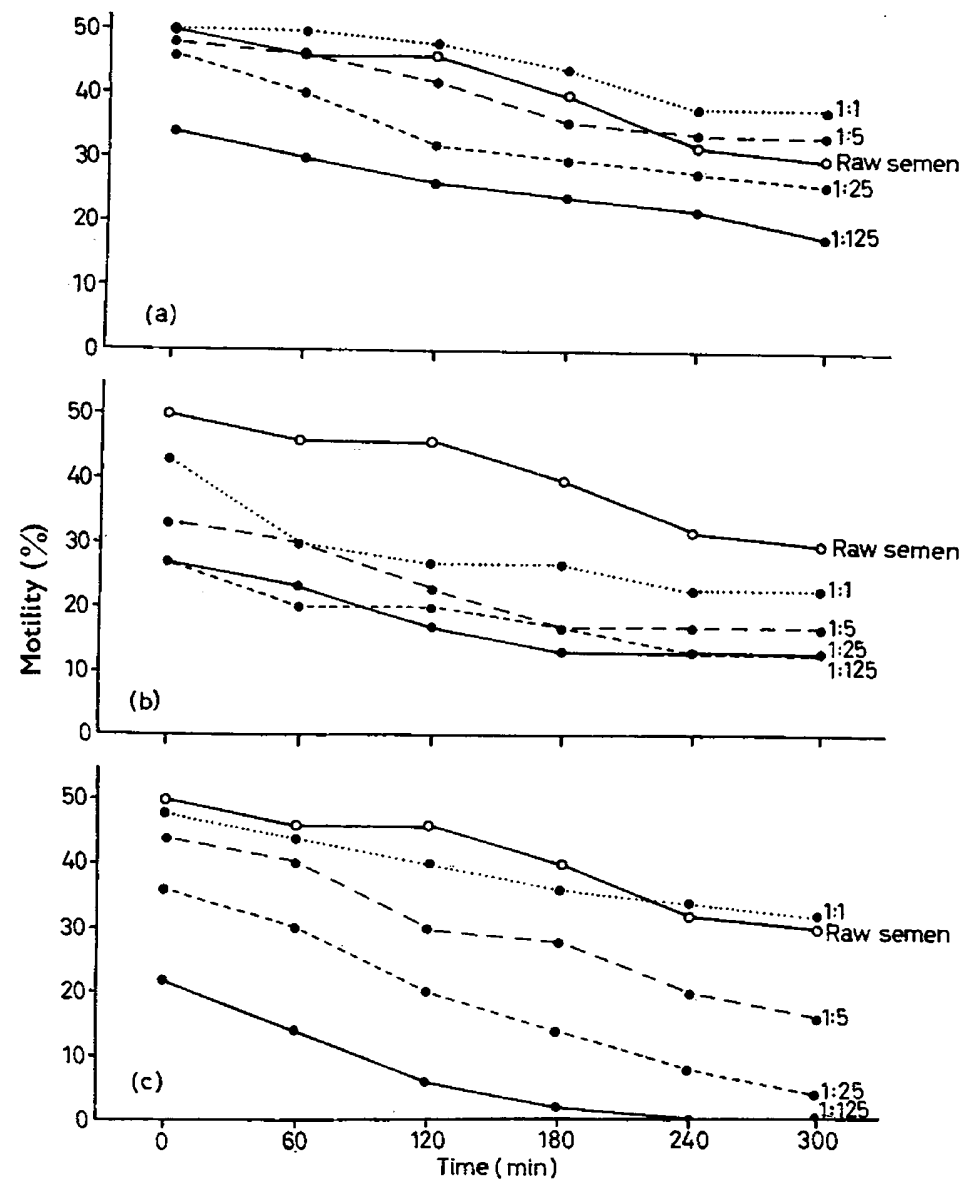

TEXT-FIG. 1. Effect of diluent and of dilution rate on sperm motility. (a) NormanJohnson-Solution 1, (b) Seminal plasma, (c) White's phosphate.

Norman-Fohnson-Solution 1 (' $\left.\mathcal{N}-\mathcal{J}-\mathrm{I}^{\prime}\right)$. $\mathrm{N}-\mathrm{J}-1$ is a relatively complex solution, 0.0734 M-sodium citrate, 0.0204 M-calcium nitrate, $0.0018 \mathrm{M}$-magnesium sulphate, $0.0024 \mathrm{M}$-sodium sulphate, $0.0014 \mathrm{M}$-potassium nitrate, $0.0015 \mathrm{M}$ potassium chloride, $0.0002 \mathrm{M}$-monosodium phosphate, with the addition of 500 mg\% glucose (Norman et al., 1960, 1961; Norman, 1961).

Physiological saline. This solution was made up with $0.9 \%$ sodium chloride and $500 \mathrm{mg} \%$ glucose. 
Phosphate diluter. This diluent is a modification $(0.0329$ M-monosodium phosphate, $0.0406 \mathrm{M}$-disodium phosphate, $0.0360 \mathrm{M}$-sodium chloride, 0.0010 M-magnesium chloride, 0.0040 M-potassium chloride) of a formula developed by White (1954) with the addition of $500 \mathrm{mg} \%$ glucose.

Seminal plasma. Seminal plasma was prepared by an initial centrifugation at

TABLE 1

EFFECT OF DILUENT AND OF DILUTION RATE ON SPERM MOTILITY (FIVE POOLED SPECIMENS)

\begin{tabular}{|c|c|c|c|c|c|c|c|c|c|c|c|c|}
\hline \multirow{3}{*}{ Treatment } & \multicolumn{12}{|c|}{ Time of incubation (min) } \\
\hline & \multicolumn{2}{|c|}{0} & \multicolumn{2}{|c|}{60} & \multicolumn{2}{|c|}{120} & \multicolumn{2}{|c|}{180} & \multicolumn{2}{|c|}{240} & \multicolumn{2}{|c|}{300} \\
\hline & $M$ & $R$ & $M$ & $R$ & $M$ & $R$ & $M$ & $R$ & $M$ & $R$ & $M$ & $R$ \\
\hline Raw semen $(1.0 \mathrm{ml})$ & 50 & $5 \cdot 1$ & 46 & $4 \cdot 4$ & 46 & $4 \cdot 2$ & 40 & $3 \cdot 8$ & 32 & $3 \cdot 4$ & 30 & 3.0 \\
\hline $\begin{array}{l}\text { Semen }+ \text { Norman-Johnson-Sol. } 1 \\
1: 1 \text { dilution } \\
1: 5 \text { dilution } \\
1: 25 \text { dilution } \\
1: 125 \text { dilution }\end{array}$ & $\begin{array}{l}50 \\
48 \\
46 \\
34\end{array}$ & \begin{tabular}{|l|}
$5 \cdot 6$ \\
$5 \cdot 2$ \\
$4 \cdot 6$ \\
$4 \cdot 0$
\end{tabular} & $\begin{array}{l}50 \\
46 \\
40 \\
30\end{array}$ & $\begin{array}{l}5 \cdot 4 \\
5 \cdot 0 \\
4 \cdot 4 \\
4 \cdot 0\end{array}$ & $\begin{array}{l}48 \\
42 \\
32 \\
26\end{array}$ & $\begin{array}{l}4 \cdot 8 \\
4 \cdot 6 \\
3 \cdot 8 \\
3 \cdot 2\end{array}$ & $\begin{array}{l}44 \\
36 \\
32 \\
24\end{array}$ & $\begin{array}{l}4 \cdot 6 \\
4 \cdot 2 \\
3 \cdot 8 \\
2 \cdot 4\end{array}$ & $\begin{array}{l}38 \\
34 \\
28 \\
22\end{array}$ & $\begin{array}{l}4 \cdot 4 \\
4 \cdot 2 \\
3 \cdot 0 \\
1 \cdot 6\end{array}$ & $\begin{array}{l}38 \\
34 \\
26 \\
18\end{array}$ & $\begin{array}{l}4 \cdot 2 \\
4 \cdot 2 \\
3 \cdot 0 \\
1 \cdot 6\end{array}$ \\
\hline $\begin{array}{c}\text { Semen }+0 \cdot 9 \% \mathrm{NaCl}+\text { glucose } \\
1: 1 \text { dilution } \\
1: 5 \text { dilution } \\
1: 25 \text { dilution } \\
1: 125 \text { dilution }\end{array}$ & $\begin{array}{l}50 \\
50 \\
46 \\
36\end{array}$ & \begin{tabular}{|}
$5 \cdot 6$ \\
$5 \cdot 0$ \\
$4 \cdot 2$ \\
$3 \cdot 6$
\end{tabular} & $\begin{array}{l}48 \\
40 \\
42 \\
26\end{array}$ & $\begin{array}{l}5 \cdot 0 \\
4 \cdot 0 \\
3 \cdot 2 \\
2 \cdot 4\end{array}$ & $\begin{array}{l}40 \\
36 \\
32 \\
20\end{array}$ & $\begin{array}{l}4 \cdot 6 \\
4 \cdot 2 \\
3 \cdot 0 \\
1 \cdot 2\end{array}$ & $\begin{array}{l}36 \\
34 \\
24 \\
12\end{array}$ & $\begin{array}{l}4 \cdot 4 \\
3 \cdot 2 \\
2 \cdot 4 \\
0 \cdot 8\end{array}$ & $\begin{array}{l}36 \\
30 \\
18 \\
10\end{array}$ & $\begin{array}{l}4 \cdot 0 \\
3 \cdot 2 \\
1 \cdot 8 \\
0 \cdot 6\end{array}$ & $\begin{array}{r}32 \\
26 \\
16 \\
8\end{array}$ & $\begin{array}{l}3 \cdot 2 \\
3 \cdot 0 \\
1 \cdot 0 \\
0 \cdot 6\end{array}$ \\
\hline $\begin{array}{l}\text { Semen }+ \text { White's } \mathrm{PO}_{4}+\text { glucose } \\
1: 1 \text { dilution } \\
1: 5 \text { dilution } \\
1: 25 \text { dilution } \\
1: 125 \text { dilution }\end{array}$ & $\begin{array}{l}48 \\
44 \\
36 \\
22\end{array}$ & $\begin{array}{l}5 \cdot 0 \\
3 \cdot 6 \\
3 \cdot 0 \\
2 \cdot 4\end{array}$ & $\begin{array}{l}44 \\
40 \\
30 \\
14\end{array}$ & $\begin{array}{l}4 \cdot 8 \\
3 \cdot 4 \\
2 \cdot 2 \\
1 \cdot 0\end{array}$ & $\begin{array}{r}40 \\
30 \\
20 \\
6\end{array}$ & $\begin{array}{l}4 \cdot 0 \\
2 \cdot 6 \\
1 \cdot 6 \\
0 \cdot 2\end{array}$ & $\begin{array}{r}36 \\
28 \\
14 \\
2\end{array}$ & $\begin{array}{l}2 \cdot 8 \\
2 \cdot 8 \\
1 \cdot 4 \\
0 \cdot 0\end{array}$ & $\begin{array}{r}34 \\
20 \\
8 \\
0\end{array}$ & $\begin{array}{l}2 \cdot 8 \\
1 \cdot 4 \\
0 \cdot 6 \\
0 \cdot 0\end{array}$ & $\begin{array}{r}32 \\
16 \\
4 \\
0\end{array}$ & $\begin{array}{l}2 \cdot 8 \\
1.0 \\
0 \cdot 0 \\
0 \cdot 0\end{array}$ \\
\hline $\begin{array}{l}\text { Semen }+ \text { seminal plasma } \\
1: 1 \text { dilution } \\
1: 5 \text { dilution } \\
1: 25 \text { dilution } \\
1: 125 \text { dilution }\end{array}$ & $\begin{array}{l}43 \\
33 \\
27 \\
27\end{array}$ & \begin{tabular}{|l|}
$4 \cdot 7$ \\
$3 \cdot 0$ \\
$2 \cdot 3$ \\
$1 \cdot 0$
\end{tabular} & $\begin{array}{l}30 \\
30 \\
20 \\
23\end{array}$ & $\begin{array}{l}2 \cdot 7 \\
2 \cdot 3 \\
1 \cdot 7 \\
1 \cdot 7\end{array}$ & $\begin{array}{l}27 \\
23 \\
20 \\
17\end{array}$ & $\begin{array}{l}2 \cdot 3 \\
2 \cdot 0 \\
1 \cdot 7 \\
1 \cdot 3\end{array}$ & $\begin{array}{l}27 \\
17 \\
17 \\
13\end{array}$ & $\begin{array}{l}2 \cdot 3 \\
2 \cdot 0 \\
1 \cdot 7 \\
1 \cdot 0\end{array}$ & $\begin{array}{l}23 \\
17 \\
13 \\
13\end{array}$ & $\begin{array}{l}2 \cdot 3 \\
1 \cdot 7 \\
1 \cdot 3 \\
1 \cdot 0\end{array}$ & $\begin{array}{l}23 \\
17 \\
13 \\
13\end{array}$ & $\begin{array}{l}2 \cdot 3 \\
1 \cdot 7 \\
1 \cdot 0 \\
1 \cdot 0\end{array}$ \\
\hline $\begin{array}{c}\text { Semen }+ \text { bovine semen diluent } \\
1: 1 \text { dilution } \\
1: 5 \text { dilution } \\
1: 25 \text { dilution } \\
1: 125 \text { dilution }\end{array}$ & $\begin{array}{l}26 \\
28 \\
18 \\
10\end{array}$ & $\begin{array}{l}2 \cdot 0 \\
1 \cdot 6 \\
0 \cdot 8 \\
0 \cdot 6\end{array}$ & $\begin{array}{r}24 \\
20 \\
12 \\
6\end{array}$ & $\begin{array}{l}2 \cdot 0 \\
1 \cdot 4 \\
0 \cdot 8 \\
0 \cdot 2\end{array}$ & $\begin{array}{r}24 \\
16 \\
8 \\
4\end{array}$ & $\begin{array}{l}2 \cdot 0 \\
0 \cdot 8 \\
0 \cdot 4 \\
0 \cdot 2\end{array}$ & $\begin{array}{r}24 \\
12 \\
8 \\
2\end{array}$ & $\begin{array}{l}1.8 \\
0.6 \\
0.2 \\
0.0\end{array}$ & $\begin{array}{r}22 \\
10 \\
6 \\
2\end{array}$ & $\begin{array}{l}1 \cdot 8 \\
0 \cdot 2 \\
0 \cdot 2 \\
0 \cdot 0\end{array}$ & $\begin{array}{r}18 \\
8 \\
4 \\
2\end{array}$ & $\begin{array}{l}1.6 \\
0.0 \\
0.0 \\
0.0\end{array}$ \\
\hline $\begin{array}{c}\text { Semen }+ \text { Ill. var. temp. dil. } \\
1: 1 \text { dilution } \\
1: 5 \text { dilution } \\
1: 25 \text { dilution } \\
1: 125 \text { dilution }\end{array}$ & $\begin{array}{r}40 \\
24 \\
8 \\
4\end{array}$ & $\begin{array}{l}2 \cdot 8 \\
2 \cdot 2 \\
0 \cdot 8 \\
0 \cdot 2\end{array}$ & $\begin{array}{r}36 \\
20 \\
4 \\
4\end{array}$ & $\begin{array}{l}2 \cdot 4 \\
1 \cdot 8 \\
0 \cdot 4 \\
0 \cdot 2\end{array}$ & $\begin{array}{r}34 \\
16 \\
0 \\
0\end{array}$ & $\begin{array}{l}2 \cdot 2 \\
1 \cdot 0 \\
0 \cdot 0 \\
0 \cdot 0\end{array}$ & $\begin{array}{r}28 \\
10 \\
0 \\
0\end{array}$ & $\begin{array}{l}2 \cdot 0 \\
0 \cdot 8 \\
0 \cdot 0 \\
0 \cdot 0\end{array}$ & $\begin{array}{r}22 \\
8 \\
0 \\
0\end{array}$ & $\begin{array}{l}1 \cdot 6 \\
0 \cdot 6 \\
0 \cdot 0 \\
0 \cdot 0\end{array}$ & $\begin{array}{r}12 \\
4 \\
0 \\
0\end{array}$ & $\begin{array}{l}0 \cdot 8 \\
0 \cdot 2 \\
0 \cdot 0 \\
0 \cdot 0\end{array}$ \\
\hline
\end{tabular}

$M=$ Motility $(\%) ; R=$ Rate of forward progression.

$600 \mathrm{~g}$ for $10 \mathrm{~min}$ to pack the cells, followed by decantation of the plasma and its centrifugation at $1500 \mathrm{~g}$ for $30 \mathrm{~min}$. This plasma is cell-free as far as can be determined by examination of smears under the microscope.

Bovine semen diluent. This is a patented proprietary commercial formulation (Nasco, Fort Atkinson, Wisconsin), prepared for use as a diluent for bull semen in artificial insemination. The active ingredients listed on the package 
include carboxymethoxylamine hemihydrochloride, sodium dehydroacetic acid, 9-aminoacridine-HCl, sulphanilamide, sodium citrate, dextrose, egg.

Illinois variable temperature diluent. This formulation is a commercially available egg-yolk citrate preparation (Nasco, Fort Atkinson, Wisconsin) for extending bull semen and is a modification of the diluent developed by VanDemark \& Sharma (1957). The manufacturer reserves the right to disclose the exact composition of diluents 5 and 6 directly to interested research workers.

The percentage motility and forward progression ratings were made at $37^{\circ} \mathrm{C}$ on dilutions of five pooled semen specimens, except in the case of seminal plasma where sufficient volume of plasma was available from only three of the five pooled specimens.

The motility immediately after dilution and the maintenance of motility upon incubation were a function of diluent and of dilution rate (Table 1 and

TABLE 2

ANALYSIS OF VARIANGE OF THE EFFECTS OF DILUENT AND OF DILUTION RATE ON SPERM MOTILITY (FIVE POOLED SPECIMENS)

\begin{tabular}{|c|c|c|c|}
\hline Source of variation & Symbol & Degrees of freedom & Mean square \\
\hline $\begin{array}{l}\text { Specimen } \\
\text { Diluent } \\
\text { Dilution rate } \\
\text { Time } \\
\mathrm{S} \times \mathrm{D} \\
\mathrm{S} \times \mathrm{R} \\
\mathrm{S} \times \mathrm{T} \\
\mathrm{D} \times \mathrm{R} \\
\mathrm{D} \times \mathrm{T} \\
\mathrm{R} \times \mathrm{T} \\
\mathrm{S} \times \mathrm{D} \times \mathrm{R} \\
\mathrm{S} \times \mathrm{D} \times \mathrm{T} \\
\mathrm{S} \times \mathrm{R} \times \mathrm{T} \\
\mathrm{D} \times \mathrm{R} \times \mathrm{T} \\
\text { Residual }\end{array}$ & $\begin{array}{l}\text { S } \\
\text { D } \\
\text { R } \\
\text { T } \\
\text { SD } \\
\text { SR } \\
\text { ST } \\
\text { DR } \\
\text { DT } \\
\text { RT } \\
\text { SDR } \\
\text { SDT } \\
\text { SRT } \\
\text { DRT }\end{array}$ & $\begin{array}{r}4 \\
5 \\
3 \\
5 \\
20 \\
12 \\
20 \\
15 \\
25 \\
15 \\
60 \\
100 \\
60 \\
75 \\
252\end{array}$ & $\begin{array}{c}858 \cdot 43 \\
8956 \cdot 23^{*} \\
12959 \cdot 83^{*} \\
3524 \cdot 56^{*} \\
327 \cdot 12 \\
33 \cdot 42 \\
40.90 \\
507 \cdot 65^{*} \\
52 \cdot 26 \\
49 \cdot 95^{*} \\
214 \cdot 14^{*} \\
34 \cdot 07^{* *} \\
21 \cdot 89^{*} \\
34 \cdot 59^{*} \\
0 \cdot 43\end{array}$ \\
\hline
\end{tabular}

Text-fig. 1). Immediately upon treatment, dilution with the diluents based on egg-yolk citrate (Diluent 5, 1.0\% citrate and Diluent 6, 1.8\% citrate) resulted in a marked decrease in percentage motility and in an almost complete cessation of forward progression (Table 1). In earlier work (MacLeod \& Freund, 1958; Freund \& MacLeod, 1958), and in the preliminary work for this study, it was noted that $2.9 \%$ sodium citrate, a standard diluent for bull semen, was extremely toxic to human spermatozoa in that it arrested their motility within seconds after dilution. This is particularly striking in view of the fact that the best diluent in this series, $\mathrm{N}-\mathrm{J}-1$, is also based on sodium citrate $(2 \cdot 2 \%)$. It has been suggested by Dr Charles Norman, who developed N-J-1, that the high calcium concentration in this solution results in the formation of citrate complexes which are not detrimental to sperm motility. The addition of excess calcium after human spermatozoa have been immobilized by citrate does not reverse the process. 
$\mathrm{N}-\mathrm{J}-1$ was superior to all of the other diluents, at all dilution rates, in terms of the maintenance of motility and progression during the $300-$ min incubation period. Dilution with $\mathrm{N}-\mathrm{J}-1$, at $1: 1$ and $1: 5$, resulted in the maintenance of sperm motility and progression at the level of that in the undiluted raw semen and, at $1: 25$, in the maintenance of a level only slightly inferior to that in the raw semen. Dilution with either saline or phosphate, at $1: 1$, resulted in a maintenance of spermatozoal motility equal to that in the raw semen, but higher dilutions resulted in greater loss of motility and progression. The seminal plasma was a relatively poor diluent and was inferior in every respect to $\mathrm{N}-\mathrm{J}-\mathrm{l}$ and to saline.

A statistical analysis of these data (Table 2) indicates the importance of the evident differences in the maintenance of spermatozoal motility among diluents and among dilution rates. The significance of the Diluent $\times$ Dilution rate interaction term (Table 2) confirms the observation (Table 1) that some of the solutions are useless at the higher dilutions. The significant Dilution rate $\times$ Time interaction term suggests the existence of a true 'dilution effect' since, across all solutions, the higher dilution rates resulted in more rapid and more complete loss of motility and progression with time.

EFFECT OF RATE OF COOLING FROM +25 TO $+5^{\circ}$ C ON SPERMATOZOAL MOTILITY

The rate of cooling from room temperature $\left(\cong+25^{\circ} \mathrm{C}\right)$ to working temperature $\left(\cong+5^{\circ} \mathrm{C}\right)$ is critical for bull spermatozoa and rapid cooling in this range results in cold shock, a rapid and irreversible loss of motility, metabolic activity and fertility. Sherman (1955) claimed that human spermatozoa were not susceptible to cold shock. Recently, he modified this view and concluded (1963) that about one-half of the specimens tested did show cold shock effects but that the loss of motility in human semen was less than that in bull semen.

The effects of 'fast cooling' ( +25 to $+5^{\circ} \mathrm{C}$ in less than $\left.10 \mathrm{~min}\right)$ and of 'slow cooling' ( +25 to $+5^{\circ} \mathrm{C}$ in $4 \mathrm{hr}$ ) on spermatozoal motility in raw semen were compared. Both fast and slow cooling were shown to be markedly detrimental to the motility and forward progression of twenty-five raw semen specimens when ratings were made at 30 -min intervals for $240 \mathrm{~min}$ (Table 3 ). It was not the rate of cooling, per se, but the lower temperatures themselves which seemed to be harmful. These data agree with those of Sawada (1964). These data and Sawada's work (1964) may be used to explain the physiological basis for some of the procedures developed by Sherman $(1954,1955,1962,1963)$ for the freezing of raw human semen. Sherman reported no effect of cold shock (1955), or only a very slight effect (1963), because he examined the specimens as rapidly as possible after 'cold shocking' and re-warming them and did not follow them for $4 \mathrm{hr}$, as was done in this study (Table 3), or for $24 \mathrm{hr}$, as was done by Sawada (1964). Marked detrimental effects of cooling on motility may be seen at $60 \mathrm{~min}$ or even at $30 \mathrm{~min}$, but apparently not before that time (Sherman, 1963). Sherman was correct in concluding that raw human semen had to be frozen as soon as possible rather than held and treated for several hours prior to freezing, but this was not because immediate freezing was so successful (post-thaw motilities $=29$ to $35 \%$, Sherman, 1963), but rather 


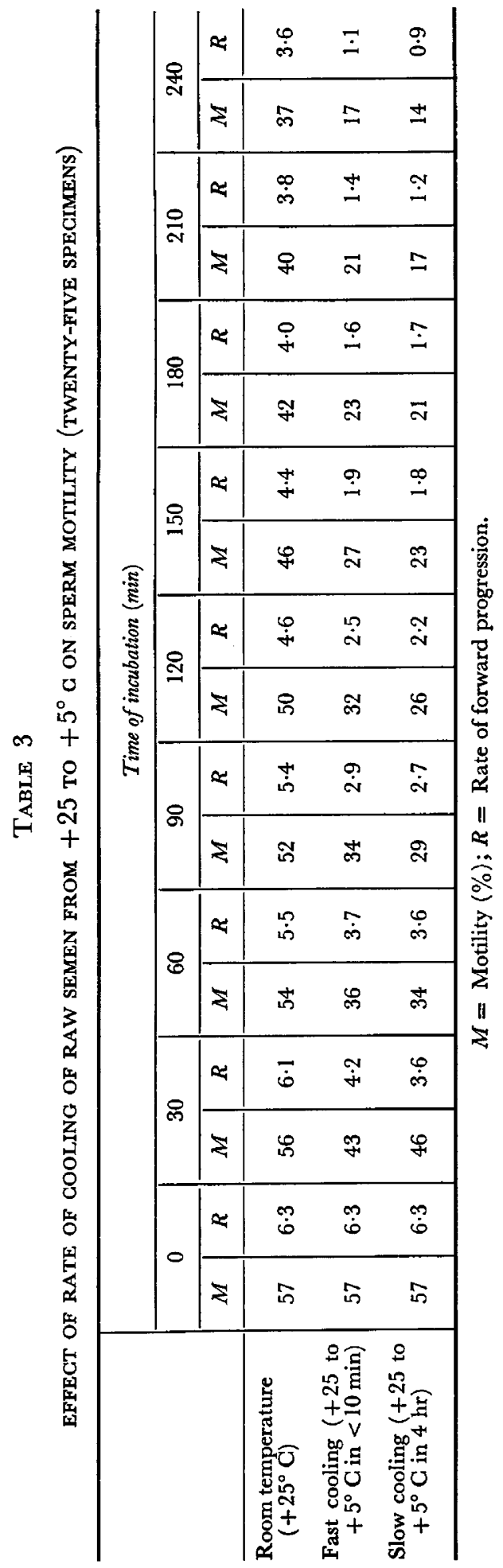


because there were no workable methods for maintaining spermatozoal motility and viability at acceptable levels in raw semen during extended prefreezing treatment periods.

The results are, however, quite different when semen which has been diluted with a good diluent, e.g. N-J-1, is cooled from +25 to $+5^{\circ} \mathrm{C}$. In this case (Table 4) spermatozoal motility was maintained as well for 240 min in semen diluted with N-J-1 and 'slow cooled' to $+5^{\circ} \mathrm{C}$ over a 4-hr period, as in semen diluted with N-J-1 and incubated at $+25^{\circ} \mathrm{C}$. The addition of $10 \%$ egg yolk had a slight but consistent beneficial effect, particularly during the first $120 \mathrm{~min}$, but no statistically significant effect was noted over the entire 240 -min period. Evidently, the N-J-1 diluent exerted a protective and beneficial effect on the

\section{TABLE 4}

EFFECT OF DILUTION AND OF ADDED EGG YOLK ON SPERM MOTILITY IN SEMEN 'SLOWCOOLED' FROM +25 TO $+5^{\circ}$ G (FOURTEEN SPECIMENS)

\begin{tabular}{|c|c|c|c|c|c|c|c|c|c|c|}
\hline & \multicolumn{10}{|c|}{ Time of incubation (min) } \\
\hline & \multicolumn{2}{|c|}{0} & \multicolumn{2}{|c|}{60} & \multicolumn{2}{|c|}{120} & \multicolumn{2}{|c|}{180} & \multicolumn{2}{|c|}{240} \\
\hline & $M$ & $R$ & $M$ & $R$ & $M$ & $R$ & $M$ & $R$ & $M$ & $R$ \\
\hline $\begin{array}{l}\text { Semen diluted } 1: 5 \text { with } \\
N-J-1 \text {; at room temp. } \\
\left(+25^{\circ} \mathrm{C}\right)^{*}\end{array}$ & 57 & $6 \cdot 2$ & 55 & $5 \cdot 2$ & 51 & $5 \cdot 0$ & 43 & 3.9 & 43 & $3 \cdot 8$ \\
\hline $\begin{array}{l}\text { Semen diluted } 1: 5 \text { with } \\
\mathrm{N}-\mathrm{J}-1 ; \text { slow cooled } \\
\left(+25 \text { to }+5^{\circ} \mathrm{C} \text { in }\right. \\
4 \mathrm{hr})^{*}\end{array}$ & 57 & $6 \cdot 2$ & 51 & $5 \cdot 1$ & 47 & $4 \cdot 8$ & 46 & $4 \cdot 2$ & 41 & $3 \cdot 6$ \\
\hline $\begin{array}{l}\text { Semen diluted I : } 5 \text { with } \\
\mathrm{N}-\mathrm{J}-1 \text {; slow cooled; } \\
10 \% \text { egg yolk added } \dagger\end{array}$ & 57 & $6 \cdot 2$ & 57 & $6 \cdot 1$ & 52 & $5 \cdot 6$ & 43 & $4 \cdot 3$ & 41 & 4.0 \\
\hline
\end{tabular}

$M=$ Motility (\%); $R=$ Rate of forward progression.

$* 0.5 \mathrm{ml}$ semen $+2.0 \mathrm{ml} \mathrm{N}-\mathrm{J}-1$.

$\dagger 0.5 \mathrm{ml}$ semen $+2.0 \mathrm{ml} \mathrm{N}-\mathrm{J}-1+0.25 \mathrm{ml}$ egg yolk.

maintenance of spermatozoal motility during cooling to and incubation at $+5^{\circ} \mathrm{C}$.

Of interest is the observation that a large part of the cooling damage is done to both the 'fast-cooled' and 'slow-cooled' raw semen by 60 min of incubation (Table 3), while semen diluted $1: 5$ with $\mathrm{N}-\mathrm{J}-1$ is relatively unaffected during the first $60 \mathrm{~min}$ of slow cooling (Table 4). 'Fast cooling' has been defined by Sherman (1963), and in this study, as a drop in temperature from +25 to $+5^{\circ} \mathrm{C}$ in $10 \mathrm{~min}$. No data, however, have been published on the actual rate of drop in temperature during 'slow cooling' of small volumes of raw or diluted human semen and the slow-cooling process, i.e. the cooling of the semen from +25 to $+5^{\circ} \mathrm{C}$ in 3 to $5 \mathrm{hr}$, is itself of interest. When $4 \mathrm{ml}$ of raw or diluted semen is placed in a $25-\mathrm{ml}$ T-stoppered flask, the flask suspended in $400 \mathrm{ml}$ of water at $+25^{\circ} \mathrm{C}$ in a $600 \mathrm{ml}$ beaker, the beaker placed in a $+5^{\circ} \mathrm{C}$ constant temperature chamber and the temperature recorded at 30 -min intervals, it 
becomes apparent that the rate of decrease in temperature is not constant during the whole of the cooling period. There was a rapid decline in temperature during the first hour $\left(25.0\right.$ to $\left.12.9^{\circ} \mathrm{C}\right)$, followed by increasingly smaller declines in each succeeding hour (second hour: 12.9 to $8.8^{\circ} \mathrm{C}$; third hour: 8.8 to $7.0^{\circ} \mathrm{C}$; fourth hour: 7.0 to $6.2^{\circ} \mathrm{C}$; fifth hour: 6.2 to $5.9^{\circ} \mathrm{C}$ ). When these data are traced on an arith-arith plot, this change in rate of cooling becomes evident (Text-fig. 2). These data were also plotted on semi-log paper, but did not yield the straight line which might have been expected. However, when the data were plotted on $\log -\log$ paper, a straight line could be drawn through the points (Text-fig. 2), which indicates that conditions inside the flask were not constant during the successive time periods. It is suggested that the stirring action of the motile spermatozoa and the viscosity of the seminal plasma may account for this phenomenon. At the beginning of the cooling period, i.e. during the first hour, the relatively vigorous spermatozoal motility resulted in a more rapid cooling rate as compared to that recorded with $4 \mathrm{ml}$ of distilled water
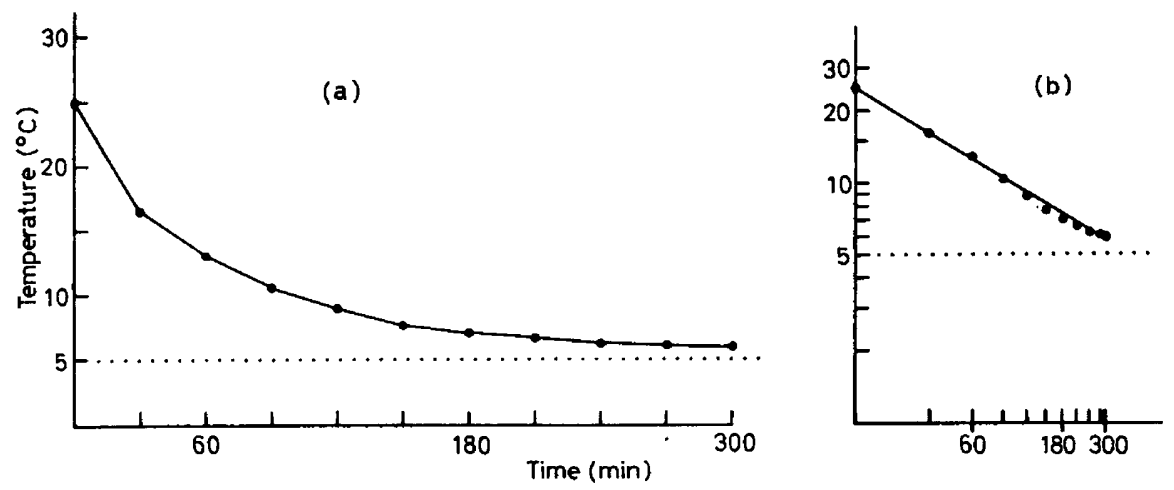

TEXT-FIG. 2. Arith-arith (a) and $\log -\log$ (b) plots of the change in rate of cooling of semen from +25 to $+5^{\circ} \mathrm{C}$.

in the flask (first hour: 25.0 to $14 \cdot 4^{\circ} \mathrm{C}$ ). However, the cooling rate of the water was the same during the second hour $\left(14.4\right.$ to $10.3^{\circ} \mathrm{C}$ ) and was faster during the succeeding periods (third hour: 10.3 to $7.8^{\circ} \mathrm{C}$; fourth hour: 7.8 to $6.4^{\circ} \mathrm{C}$; fifth hour: 6.4 to $5.7^{\circ} \mathrm{C}$ ). This may be interpreted to indicate that during the second and succeeding hours there was a steady decrease in the motility and, therefore, in the stirring effect of the spermatozoa with the result that, during the third, fourth and fifth hours, the rate of cooling of the distilled water exceeded that of the semen because of the higher viscosity of the semen.

\section{FREEZING AND STORAGE OF SEMEN DILUTED $1: 5$ WITH NORMAN-JOHNSON-SOLUTION 1}

In a series of preliminary trials, it was determined that: (1) a final concentration of $7 \%$ glycerol in the diluted semen resulted in greater spermatozoal survival after freezing than did either $3 \frac{1}{2}$ or $10 \%$ glycerol; (2) $7 \%$ glycerol was markedly protective against freezing damage while $7 \%$ dimethylsulphoxide 
gave little protection; (3) $6 \mathrm{hr}$ of equilibration of the diluted semen with $7 \%$ glycerol at $+5^{\circ} \mathrm{C}$ was equal to or superior to either 12 or $18 \mathrm{hr}$ of equilibration; (4) constant magnetic stirring yielded a homogeneous mixture of cells, plasma, diluent, egg yolk and glycerol and was not detrimental to sperm motility; and (5) the use of a very slow freezing rate, i.e. $-1^{\circ} \mathrm{C} / \mathrm{min}$, resulted in better and more uniform spermatozoal survival than did the use of faster rates of freezing.

After this series of preliminary trials, six freezing experiments were made on pooled semen specimens, using the complete seven-step procedure described in 'Methods'. This procedure is based on the published details of the methods for freezing bull semen, the experience developed in the preliminary work in this study and on several refinements developed during the course of the study. The survival of the spermatozoa, in pooled semen specimens diluted $1: 5$ with $\mathrm{N}-\mathrm{J}-1$ with the addition of $10 \%$ egg yolk and $7 \%$ glycerol, slow cooled from +25 to $+5^{\circ} \mathrm{C}$, and frozen at the rate of $-1^{\circ} \mathrm{C} / \mathrm{min}$ from +5 to $-70^{\circ} \mathrm{C}$,

TABLE 5

FREEZING AND STORAGE OF SEMEN DILUTED $1: 5$ WITH NORMAN-JOHNSON-SOLUTION 1

\begin{tabular}{|c|c|c|c|c|c|c|}
\hline \multirow{2}{*}{$\begin{array}{c}\text { Experiment } \\
\text { No. }\end{array}$} & \multirow{2}{*}{$\begin{array}{c}\text { Motility } \\
\text { of } \\
\text { raw semen }\end{array}$} & \multirow{2}{*}{$\begin{array}{c}\text { Motility after } \\
4 \text { hr slow } \\
\text { cooling } \\
\text { and } 6 \text { hr } \\
\text { equilibration }\end{array}$} & \multicolumn{4}{|c|}{ Motility after storage period $\dagger$} \\
\hline & & & 1 day & $8-9$ months & 14-15 months & 23-24 months \\
\hline $\begin{array}{l}\text { A1 } \\
\text { A2 } \\
\text { A3 } \\
\text { A4 } \\
\text { A5 } \\
\text { A6 }\end{array}$ & $\begin{array}{l}70-8 * \\
60-8 \\
60-8 \\
50-8 \\
80-9 \\
70-7\end{array}$ & $\begin{array}{l}60-8 \\
60-7 \\
60-8 \\
50-8 \\
80-9 \\
60-7\end{array}$ & $\begin{array}{l}60-7 \\
60-7 \\
60-7 \\
50-7 \\
60-8 \\
60-5\end{array}$ & $\begin{array}{l}40-6 \\
50-6 \\
60-7 \\
50-7 \\
60-7 \\
60-5\end{array}$ & $\begin{array}{l}20-2 \\
30-4 \\
25-3 \\
30-4 \\
30-4 \\
40-5\end{array}$ & $\begin{array}{l}\$ \\
30 \pm 5 \\
40-3 \\
35-5 \\
40-4 \\
40-5\end{array}$ \\
\hline
\end{tabular}

* Motility (\%) and rate of forward progression.

$\dagger$ Stored at -76 to $-85^{\circ} \mathrm{C}$.

$\ddagger$ No ampoules remaining.

was excellent as measured by motility ratings (Table 5 ). Spermatozoal viability after 8 to 9 months of storage at $-85^{\circ} \mathrm{C}$, as measured by percentage motility and by rate of forward progression, was very good with only one specimen showing an appreciable decline in motility (Experiment A1, Table 5). However, after 14 to 15 months of storage, there was a marked decline in motility which was apparent in every specimen examined. The 1-ml ampoules of frozen semen were stored in racks set in trays filled with isopropyl alcohol. The trays were placed in metal racks which were stored in a mechanical refrigerator set at $-85^{\circ} \mathrm{C}$ (range $=-82$ to $-87^{\circ} \mathrm{C}$ ). Slabs of dry ice were placed on all four sides and on top of the racks to act as a reserve in case of mechanical failure. The mechanical freezer failed three times during months 9 to 24 of the storage period and for 2 to 3 days at a time the temperature rose to $-76^{\circ} \mathrm{C}$, the temperature maintained by the dry ice reserve in the freezer. Thus, it is not possible to decide directly whether $-85^{\circ} \mathrm{C}$ was not a low enough temperature for the long-term storage of human semen or whether the problem of the 
mechanical failures and the resulting short periods of storage at $-76^{\circ} \mathrm{C}$ was the critical factor. Nevertheless, in view of the reports by Pickett, Fowler \& Cowan (1960) that the motility of bull spermatozoa was maintained at a higher level upon storage at $-196^{\circ} \mathrm{C}$ than at $-79^{\circ} \mathrm{C}$ and by Sherman (1963) that frozen raw human semen, stored at $-75^{\circ} \mathrm{C}$ for 12 months, declined in percentage motility, while semen stored at $-196^{\circ} \mathrm{C}$ did not, it seems reasonable to conclude that $-196^{\circ} \mathrm{C}$, the temperature of liquid nitrogen, is required for the long-term storage of diluted human semen, while long-term storage at -75

TABLE 6

COMPARISON OF NORMAN-JOHNSON-SOLUTION 1 ( $\mathrm{N}-\mathrm{J}-1$ ) AND NORMAN-JOHNSONSOLUTION 2 (N-J-2) AS DILUENTS FOR USE IN FREEZING

\begin{tabular}{|c|c|c|c|c|c|c|c|c|}
\hline \multirow{2}{*}{$\begin{array}{c}\text { Ex- } \\
\text { peri- } \\
\text { ment } \\
\text { No. }\end{array}$} & \multirow{2}{*}{ Diluent } & \multirow{2}{*}{$\begin{array}{l}\text { Motility } \\
\text { of raw } \\
\text { semen }\end{array}$} & \multirow{2}{*}{$\begin{array}{c}\text { Motility } \\
\text { after } 4 \mathrm{hr} \\
\text { slow cooling } \\
\text { and } 6 \mathrm{hr} \\
\text { equilibration }\end{array}$} & \multicolumn{5}{|c|}{ Motility after storage period $\dagger$} \\
\hline & & & & $\begin{array}{c}1 \\
\text { day }\end{array}$ & $\begin{array}{c}1-2 \\
\text { months }\end{array}$ & $\begin{array}{c}7-8 \\
\text { months }\end{array}$ & $\begin{array}{l}14-15 \\
\text { months }\end{array}$ & $\begin{array}{l}22-23 \\
\text { months }\end{array}$ \\
\hline A7 & $\begin{array}{l}\mathrm{N}-\mathrm{J}-1 \\
\mathrm{~N}-\mathrm{J}-2\end{array}$ & $70-8^{*}$ & $\begin{array}{l}60-6 \\
60-6\end{array}$ & $\begin{array}{l}50-6 \\
50-6\end{array}$ & 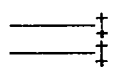 & $\begin{array}{l}50-6 \\
50-6\end{array}$ & $\begin{array}{l}30-3 \\
40-4\end{array}$ & $\overline{40-4}$ \\
\hline A8 & $\begin{array}{l}\mathrm{N}-\mathrm{J}-1 \\
\mathrm{~N}-\mathrm{J}-2\end{array}$ & $50-6$ & $\begin{array}{l}50-6 \\
50-6\end{array}$ & $\begin{array}{l}40-5 \\
40-5\end{array}$ & $\longrightarrow \neq$ & $\begin{array}{l}30-5 \\
30-5\end{array}$ & $\begin{array}{l}10-2 \\
10-2\end{array}$ & $\stackrel{10-3}{-}$ \\
\hline A9 & $\begin{array}{l}\mathrm{N}-\mathrm{J}-1 \\
\mathrm{~N}-\mathrm{J}-2\end{array}$ & $60-7$ & $\begin{array}{l}50-7 \\
50-7\end{array}$ & $\begin{array}{l}50-7 \\
50-7\end{array}$ & - & $\begin{array}{l}50-7 \\
50-7\end{array}$ & $\begin{array}{l}50-6 \\
50-5\end{array}$ & $\stackrel{50-6}{-}$ \\
\hline $\mathrm{A} 10$ & $\begin{array}{l}\mathrm{N}-\mathrm{J}-1 \\
\mathrm{~N}-\mathrm{J}-2\end{array}$ & $70-8$ & $\begin{array}{l}50-5 \\
50-5\end{array}$ & $\begin{array}{l}50-5 \\
50-5\end{array}$ & $\begin{array}{l}50-6 \\
50-6\end{array}$ & $\begin{array}{l}40-5 \\
50-5\end{array}$ & $\begin{array}{l}15-3 \\
10-3\end{array}$ & $\begin{array}{l}20-4 \\
20-4\end{array}$ \\
\hline All & $\begin{array}{l}N-J-1 \\
N-J-2\end{array}$ & $70-9$ & $\begin{array}{l}70-7 \\
70-7\end{array}$ & $\begin{array}{l}60-6 \\
60-6\end{array}$ & $\begin{array}{l}50-7 \\
50-7\end{array}$ & $\begin{array}{l}50-5 \\
50-5\end{array}$ & $\begin{array}{l}35-4 \\
25-4\end{array}$ & $\overline{35-4} \int$ \\
\hline A12 & $\begin{array}{l}\mathrm{N}-\mathrm{J}-1 \\
\mathrm{~N}-\mathrm{J}-2\end{array}$ & $70-7$ & $\begin{array}{l}70-7 \\
70-7\end{array}$ & $\begin{array}{l}60-6 \\
60-6\end{array}$ & $\begin{array}{l}50-5 \\
50-7\end{array}$ & $\begin{array}{l}40-5 \\
50-5\end{array}$ & $\begin{array}{l}30-4 \\
40-4\end{array}$ & $\begin{array}{l}30-3 \\
40-3\end{array}$ \\
\hline
\end{tabular}

to $-85^{\circ} \mathrm{C}$ is unsatisfactory. Long-term storage of diluted semen frozen in this laboratory is now being made in liquid nitrogen.

COMPARISON OF NORMAN-JOHNSON-SOLUTION 1 (N-J-1) AND NORMAN-JOHNSONSOLUTION 2 (N-J-2) AS DILUENTS FOR USE IN FREEZING

During August 1962, Dr Charles Norman sent to us a description of a new diluent (N-J-2), which was a modification of N-J-1 in which the molar concentrations were the same but in which chlorides were substituted in each case for the nitrates and sulphates, $0.0734 \mathrm{M}$-sodium citrate, $0.0204 \mathrm{M}$-calcium chloride, 0.0018 M-magnesium chloride, 0.0024 M-sodium chloride, 0.0028 M-potassium chloride, 0.0002 м-monosodium phosphate (Norman, 1964). In a preliminary study (five trials), N-J-2 preserved sperm motility slightly better 
than did N-J-1 at $1: 5$ and at $1: 25$ dilution upon incubation at $25^{\circ} \mathrm{C}$ for $300 \mathrm{~min}$, but the difference was not significant.

Six freezing trials were made, on pooled semen specimens, to compare $\mathrm{N}-\mathrm{J}-1$ and $\mathrm{N}-\mathrm{J}-2$ at $1: 5$ dilution for use as diluents in the freezing of human semen. The data demonstrate (Table 6) that there was no significant difference between N-J-1 and N-J-2 in terms of their utility as diluents for freezing experiments. These data also confirm the observation that human semen diluted $1: 5$ with either $\mathrm{N}-\mathrm{J}-1$ or $\mathrm{N}-\mathrm{J}-2$ may be stored for 8 months at $-85^{\circ} \mathrm{C}$ with little or no loss of viability but that there is an appreciable decline in motility after 15 months storage at $-85^{\circ} \mathrm{C}$.

It is of the greatest interest that $\mathrm{N}-\mathrm{J}-\mathrm{l}$, a diluent based on nitrates and sulphates, is an excellent medium for human spermatozoa and is as good as $\mathrm{N}-\mathrm{J}-2$, a diluent of equal molarity and cation composition but based on chlorides.

TABLE 7

FREEZING AND STORAGE OF DILUTED SEMEN WITH POOR MOTILITY

\begin{tabular}{c|c|c|c|c|c|c}
\hline $\begin{array}{c}\text { Experiment } \\
\text { No. }\end{array}$ & $\begin{array}{c}\text { Motility } \\
\text { of } \\
\text { raw semen }\end{array}$ & $\begin{array}{c}\text { Motility } \\
\text { after } 4 \mathrm{hr} \\
\text { slow cooling } \\
\text { and } 6 \text { hr } \\
\text { equilibration }\end{array}$ & \multicolumn{5}{|c}{ Motility after storage period $\dagger$} \\
\hline A13 & $50-6^{*}$ & $40-5$ & 4 day & $5-6$ months & $14-15$ months & $20-21$ months \\
\hline A14 & $50-4$ & $40-4$ & $40-4$ & $30-3$ & $20-2$ & $20-2$ \\
A15 & $50-5$ & $40-4$ & $40-4$ & $40-4$ & $25-2$ & $30-4$ \\
\hline
\end{tabular}

* Motility (\%) and rate of forward progression.

$\dagger$ Stored at -76 to $-85^{\circ} \mathrm{C}$.

\section{FREEZING AND STORAGE OF SEMEN WITH POOR MOTILITY}

Three pooled semen specimens with low initial motilities (mean $=50 \%$ motile) were diluted, processed and frozen, using N-J-2 Solution and the procedure described in 'Methods'. Spermatozoal survival after freezing was very high (Table 7) and comparable to that observed in specimens with higher initial motilities (Tables 5 and 6). However, spermatozoal viability upon storage at $-85^{\circ} \mathrm{C}$, as measured by percentage motility and by rate of forward progression, was not as good, with declines in motility noted after 5 to 6 months and with very marked declines after 13 to 14 months.

\section{DISCUSSION}

In studies of diluents for mammalian semen, it is of great importance to distinguish between the classical 'dilution effect' concept, on the one hand, and the harmful or toxic effects of any component of a given diluent, on the other hand. The 'dilution effect' hypothesis holds that the dilution of mammalian spermatozoa results in a decrease in initial motility and in the maintenance of motility upon incubation. Since it is implicit in this concept that it is the dilution, per se, 
which causes the inhibition of motility, it is a requirement in any work on this hypothesis that it be shown that the diluent under study is not, in itself, detrimental. If this is not clearly shown, it becomes impossible to distinguish among the detrimental effect of dilution, the detrimental effect of the diluent, and the interaction between the two, particularly at the higher dilution rates. In much of the early work on the dilution effect, the effects of dilution and of diluent were confounded by the use of inadequate or even toxic diluents and by inadequate experimental design. The result has been that it was erroneously concluded that human spermatozoa are difficult to dilute and that they exhibit the dilution effect to a marked degree, since all the standard bull semen diluents, based on citrate or phosphate, were very harmful to human spermatozoal motility. In fact, most of them were plainly toxic since they immobilized the spermatozoa almost immediately upon contact. This conclusion has been shown to be erroneous by Norman (1961, 1964), whose N-J-1 and N-J-2 Solutions are excellent diluents for human semen.

The use of N-J-1 and N-J-2 Solutions with human semen permits the design of critical experiments in which the effects of dilution can be distinguished from the effects of diluent. Such an experiment has been made in this study (Table 1 and Text-fig. 1). These data distinguish between the effects of dilution rate ('dilution effect') and of diluent (toxic effect). The diluents which were most detrimental were the two (No. 5 and No. 6, Table 1) which were based on the citrate solutions commonly and successfully used for bull semen. These diluents were strongly inhibitory and, even at the lower dilutions, resulted in a rapid immobilization of the spermatozoa. Their toxic effects were markedly evident at the higher dilutions $(1: 25$ and $1: 125)$ where they almost immediately resulted in a cessation of spermatozoal motility. However, when N-J-1 Solution was used, at the $1: 1$ and $1: 5$ dilution rates, motility was maintained as well as or better than in the undiluted semen (Table 1 and Text-fig. 1). This has been a consistent finding with $\mathrm{N}-\mathrm{J}-2$ Solution, as well. At the next higher dilution rate $(1: 25)$, the maintenance of motility was slightly less than that in raw semen, while at the highest dilution rate $(1: 125)$, both the initial motility and the maintenance of motility upon incubation for 300 min were markedly reduced. These data strongly indicate the existence of a true 'dilution effect', which is confirmed by the magnitude and statistical significance of the mean square for dilution rate (Table 2).

The specific ionic requirements of human spermatozoa have led to the use of diluents other than the conventional citrate or phosphate bull semen diluters, which suggests the presence of important physiological differences between human and bull spermatozoa. However, N-J-1 and N-J-2, the diluents of choice for human semen, are also excellent diluents for bull semen (Norman, 1961, 1964). Thus it cannot be concluded that the ionic requirements of human and of bull spermatozoa are completely different. Rather, it is suggested that there must be some factors in the standard citrate or phosphate diluents which are inimical to human but not to bull spermatozoa. Another possibility is that the ionic requirements of human spermatozoa are more specific and/or complex than those of bull spermatozoa so that the $\mathrm{N}-\mathrm{J}$ solutions but not the other diluents can be used with human spermatozoa. It is proposed, as a working 
hypothesis, that the differences in bull and in human spermatozoal metabolism which have been reported (Freund \& MacLeod, 1958; MacLeod \& Freund, 1958) might mediate this difference in response to diluent composition. Human spermatozoa are dependent on the glycolysis of exogenous hexose as substrate for all or, at the very least, the greatest part of the energy required for motility, while bull spermatozoa derive large amounts of metabolic energy from the Krebs cycle and have an additional source of energy in endogenous substrate.

Recently, we have examined the possibility of using tissue culture media for the dilution and freezing of human semen. Preliminary results indicate that human semen may be successfully diluted in a variety of such media, including Earle's, Hanks' and Gey's balanced salt solutions.

\section{ACKNOWLEDGMENTS}

This investigation was supported by Grant No. HD-00538-04 and, in part, by HD-00488-06 from the National Institute of Child Health and Human Development, National Institutes of Health, Public Health Service. The authors gratefully acknowledge the technical assistance of Mrs Gloria Edwards, Mr Joseph Nelson and Miss Adrienne Fried. The senior author is a Career Scientist of the Health Research Council of the City of New York (I-218).

\section{REFERENCES}

Bunge, R. G. (1960) Further observations on freezing human spermatozoa. 7. Urol. 83, 192.

Bunge, R. G., Keetrel, W. C. \& Sherman, J. K. (1954) Clinical use of frozen semen. Fert. Steril. 5,520 .

Bunge, R. G. \& Sherman, J. K. (1954) Frozen human semen. Fert. Steril. 5, 193.

FreUND, M. (1962) Interrelationships among the characteristics of human semen and factors affecting semen specimen quality. F. Reprod. Fert. 4, 143.

Freund, M. (1963) Effect of frequency of emission on semen output and an estimate of daily sperm production in man. 7. Reprod. Fert. 6, 269.

Freund, M. \& MAcLeod, J. (1958) Effect of addition of fructose and of glucose on the fructolysis and motility of human semen. 7. appl. Physiol. 13, 506.

Freund, M. \& Wrederman, J. (1962) The dilution, cooling, freezing, and storage of human spermatozoa. Proc. 2nd Ann. Meet. Am. Soc. Cell Biol., San Francisco, p. 55.

Freund, M. \& Wiederman, J. (1963) Controlling and recording rates of freezing and defrosting of human semen. 7. appl. Physiol. 18, 407.

Freund, M. \& Wiederman, J. (1964) Recovery of large numbers of motile human spermatozoa in diluted human semen after storage at $-85^{\circ} \mathrm{C}$ for periods of up to ten months. Bull. $\mathcal{N} . r$. Acad. Med. 40, 72 .

Harvey, G. (1960) The speed of human spermatozoa and the effect on it of various diluents with some preliminary observations on clinical material. 7. Reprod. Fert. 1, 84.

Hoagland, H. \& Pincus, G. (1942) Revival of mammalian spermatozoa after immersion in liquid nitrogen. 7. gen. Physiol. 25, 337.

JAHNEL, F. (1938) Uber die Widerstandsfahigkeit von menschlichen Spermatozoen gegenüber starker Kalte. Klin. Wschr. 17, 1273.

MacLeod, J. \& Freund, M. (1958) Influence of spermatozoal concentration and initial fructose level on fructolysis in human semen. 7. appl. Physiol. 13, 501.

Mixner, J. (1955) Processing, storing, and shipping frozen bull semen. Circ. New Jers. agric. Exp. Stn, p. 573.

Norman, G. (1961) Prolonged survival of metabolically and functionally active mammalian sperm at room temperature. Proc. IVth int. Congr. Anim. Reprod., The Hague, p. 939.

Norman, C. (1964) Further studies on the preservation of mammalian sperm at variable temperatures. Proc. Vth int. Congr. Anim. Reprod., Trento, p. 269.

Norman, C., Goldberg, E., Porterfield, I. D. \& Johnson, C. E. (1960) Prolonged survival of human sperm in chemically defined media at room temperatures. Nature, Lond. 188, 760. 
Norman, C., Jomnson, C. E., Porterfield, I. D., Goldberg, E. \& Dunbar, R. S. (1961) Prolonged maintenance of mammalian sperm in a chemically defined medium at room temperatures. Am. Zool. 1, 117.

PARkes, A. S. (1945) Preservation of human spermatozoa at low temperatures. Br. med. F. ii, 212.

Perloff, W. H., Steingerger, E. \& Sherman, J. K. (1964) Conception with human spermatozoa frozen by nitrogen vapor technic. Fert. Steril. 15, 501 .

Pickett, B. W., Fowler, A. K. \& Cowan, W. A. (1960) Effect of continuous and alternating storage temperatures of -79 and $-196^{\circ} \mathrm{G}$ on motility of frozen bull semen. J. Dairy Sci. 43, 281.

Polge, C., Smith, A. U. \& Parkes, A. S. (1949) Revival of spermatozoa after vitrification and dehydration at low temperatures. Nature, Lond. 164, 666.

Sawada, Y. (1964) The preservation of human semen by deep freezing. Int. F. Fert. 9, 525.

Sherman, J. K. (1954) Freezing and freeze-drying of human spermatozoa. Fert. Steril. 5, 357.

Sherman, J. K. (1955) Temperature shock in human spermatozoa. Proc. Soc. exp. Biol. Med. 88, 6.

Sherman, J. K. (1962) Improved method for frozen-storage of human spermatozoa. Fedn Proc. Fedn Am. Socs exp. Biol. 21, 436.

SHERman, J. K. (1963) Improved methods of preservation of human spermatozoa by freezing and freeze-drying. Fert. Steril. 14, 49.

Sherman, J. K. \& Bunge, R. G. (1953) Observations on preservation of human spermatozoa at low temperatures. Proc. Soc. exp. Biol. Med. 82, 686.

ShETtLes, L. B. (1940) The respiration of human spermatozoa and their response to various gases and low temperatures. Am. F. Physiol. 128, 408.

Snedecor, G. W. (1956) Statistical methods, 5th edn. Iowa State College Press, Ames.

VanDemark, N. L., Militer, W. J., Kinney, W. C., Rodriguez, C. \& Friedman, M. E. (1957) Preservation of bull semen at sub-zero temperatures. Univ. Bull. Ill. agric. Exp. Sin, p. 621.

VanDemark, N. L. \& Sharma, U. D. (1957) Preliminary fertility results from the preservation of bovine semen at room temperatures. F. Dairy Sci. 40, 438.

WHITE, I. G. (1954) The effect of some seminal constituents and related substances on diluted mammalian spermatozoa. Aust. F. biol. Sci. 7, 379.

Zimmerman, S. J., Maude, M. B. \& Moldawer, M. (1964) Freezing and storage of human semen in fifty healthy medical students. Fert. Steril. 15, 505. 